\title{
De receptie van Madelon Székely-Lulofs in de Hongaarse pers in het interbellum
}

\begin{abstract}
Madelon Székely-Lulofs occupies a distinguished place in the history of the Dutch-Hungarian literary relations. Through her marriage with Hungarian planter and writer László Székely she was able to develop closer contact with the Hungarian literary world of the 1930s than any other Dutch author in this period. The Székely-Lulofs couple considerably contributed to the strengthening of the literary relations between these two countries: thanks to their translations in the 1930s and 1940s, the Dutch readership became acquainted with some of the most outstanding Hungarian writers of the time. Furthermore, they stimulated the popularity of the Dutch literature in Hungary by translating the works of Dutch writers to Hungarian. In this paper, I focus on how her works were received in Hungary in the 1930s and compare her Dutch and Hungarian reception. My research is based on a corpus of articles published in the Hungarian (literary) press of the time.
\end{abstract}

Keywords: Dutch literature, Dutch-Hungarian literary relations, literary reception, interwar period, Madelon Székely-Lulofs

\section{Inleiding}

Naar de Hongaarse receptie van Székely-Lulofs en die van haar Hongaarse man, László Székely, werd al uitgebreid onderzoek gedaan door Gábor Pusztai. ${ }^{1}$ De

${ }^{1}$ In de afgelopen vijf jaar verschenen de volgende Nederlandstalige bijdragen van Gábor Pusztai: "Hongaren in de Nederlandse koloniën: In plaats van een inleiding". In: Acta Neerlandica. Bijdragen tot de Neerlandistiek Debrecen 12 (2016): 5-23; "De bedrieglijke verlokking van de tropen: Het vreemde in het dagboek van István Radnai”. In: Acta Neerlandica. Bijdragen tot de Neerlandistiek Debrecen 10 (2015): 185-197; "De karikatuur van de kolonie: De Delische Kunstkring en László Székely: De Delische Kunstkring en László Székely”. In: Engelbrechtová, Jana (ed.): De Nederlandstalige cultuur internatonaal: Centraal-Europa en de Lage Landen. Olomouc: Univerzita Palackého v Olomouci, 2015. 155-168; "Tropisch Boedapest?: De invloed van Madelon Székely-Lulofs en László Székely op het Hongaarse literaire leven”. In: Van Heukelom, Kris e.a. (ed.): Van Eeden tot heden: Literaire dwarsverbanden tussen Midden-Europa en de Lage Landen. Gent: Academia Press Scientific Publishers, 2013. 187-197; “Binnen en buiten de grenzen: László 
Vakgroep Nederlands van de Universiteit Debrecen heeft zelfs een geheel nummer van haar eigen reeks Acta Neerlandica aan de schrijfster gewijd. ${ }^{2}$ In mijn bijdrage probeer ik een overzicht te geven van haar Hongaarse receptie door een analyse van enkele boekbesprekingen die in het interbellum over de werken van Madelon Székely-Lulofs verschenen. Op dit moment bestaat mijn corpus uit zeven artikelen die tussen 1934 en 1938 in de literaire tijdschriften Nyugat, Napkelet en Élet, en in het dagblad Pesti Napló zijn gepubliceerd.

Om tot een conclusie te kunnen komen, is het onvermijdelijk de verschillende aspecten van het receptieproces in aanmerking te nemen. Met behulp van de terminologie van de Franse socioloog Pierre Bourdieu in verband met het veld van de culturele productie kan dit proces uiteengezet worden.

\section{Het literaire veld van Bourdieu}

Bourdieu gaat ervan uit dat de beoordeling van literaire werken een proces is waarin de 'institutionele achtergrond' een heel belangrijke rol speelt: deze bestaat vooral uit de uitgevers en de critici. Het zijn deze 'bemiddelaars' die de waarde en de betekenis van een literair werk bepalen. Het centrale concept van Bourdieus theorie is het literaire veld: het geheel van personen en instellingen die een rol spelen in de productie, de verspreiding en de consumptie van de literatuur (Bourdieu 1993: 11). De waarde van een literair werk is vooral de expressie van het literaire veld en van de daarin gelegen hiërarchie.

In het proces waarbij er specifieke waarden worden toegekend aan literaire werken, "vervult sinds de $18^{\mathrm{e}}$ eeuw de institutie literatuurkritiek een dominerende rol" (Van Rees en Dorleijn 1993: 4), en dit is ook de instelling waarop ik me zal concentreren tijdens mijn onderzoek.De verschillende deelnemers binnen het literaire veld hebben meestal verschillende verantwoordelijkheden en belangen: uitgeverijen zorgen bijvoorbeeld voor "de materiële produktie en verspreiding van literatuur" (Van Rees en Dorleijn 1993: 4) terwijl de literatuurkritiek houdt zich bezig met de zgn. symbolische productie, "het specificeren en uitdragen van bepaalde opvattingen over literatuur" (Van Rees en Dorleijn 1993: 4) - dit laatste komt tot stand o.a. via literaire tijdschriften.

\footnotetext{
Székely en het Nederlandse koloniale discours.” In: Besamusca, Emmeline e.a. (ed.): Out of the Box: Über den Wert des Grenzwertigen. Wien: Praesens Verlag, 2013: 179-192; “'Deli op z'n kop': Kritiek op de kolonie in de tekeningen van László Székely". In: Acta Neerlandica. Bijdragen tot de Neerlandistiek Debrecen 9 (2012): 115-134; "De identiteit van het vreemde: Fictie en non-fictie in het verhaal "Kapitein Christoffel" van László Székely". In: Werkwinkel: Journal Of Low Countries And South African Studies 7:1 (2012): 61-73.

${ }^{2}$ Madelon Lulofs. Acta Neerlandica. Bijdragen tot de Neerlandistiek Debrecen 5. Debrecen: Universiteit Debrecen, 2007.
} 
Een specifiek kenmerk van het literaire veld is dat het op een omgekeerde manier werkt in vergelijking met het economische veld. In het literaire veld gaat economisch succes (met name hoge oplagecijfers) niet (of niet per se) gepaard met kritische waardering.

\section{De middlebrow-roman in de Nederlandse letterkunde}

Bij het receptieonderzoek van Madelon Székely-Lulofs kan de veldtheorie van Pierre Bourdieu met het begrip 'middlebrow' aangevuld worden. Met behulp van dit concept kunnen namelijk de specifieke "standpunten en doelstellingen" van de literaire elite van Nederland in de jaren dertig uiteengezet worden (Sanders 2008: 313).

Vanaf begin jaren dertig heeft de Nederlandse literaire kritiek deze populaire romans afgewezen en heeft ze onderscheiden van de "echte", "hoge" literatuur, die volgens haar inspanning vraagt van de lezer (Van Boven 2009: 285). Het waren vooral de modernistische romans die als "ware" literatuur werden beschouwd en verdedigers van dit nieuwe proza wilden zich distantiëren van de door hen als ouderwets beoordeelde realistische traditie (Van Boven 2009: 286). Door deze romans in een aparte categorie te plaatsen - d.w.z. tussen "hoge" en "lage" literatuur - werd ook het publiek bepaald bij wie ze in de smaak vielen: dat werd voornamelijk de recent ontstane burgerlijke middenklasse (Van Boven 2009: 287-288). Deze middlebrow-cultuur kan op zich niet gedefinieerd worden; die kan alleen gepositioneerd worden tegen iets anders, en wordt op deze manier een vermenging van eigenschappen van hoge en lage literatuur.

\section{De receptie van Székely-Lulofs in Nederland en in het buitenland}

\subsection{Haar receptie in Nederland}

Székely-Lulofs' romans over Indië hebben veel lezers gevonden en zijn in de meeste grote talen beschikbaar. Bijna alle boeken van Székely-Lulofs werden vertaald, haar debuutroman Rubber zelfs in meer dan tien talen. Bovendien werd de roman in 1934 door de auteur bewerkt voor toneel en werd hij verfilmd. Rubber maakte Székely-Lulofs bekend in Nederland en ver daarbuiten, en het is haar populairste roman gebleven. Eigenlijk was ze "acht jaar na haar debuut met de roman Rubber [...] de bekendste Nederlandse auteur van haar tijd - in binnen- en buitenland" (Praamstra 2007: 89).

Volgens Olf Praamstra is haar populariteit in Nederland in de jaren dertig in hoge mate te danken aan "het realistische gehalte van haar werk" (Praamstra 2007: 92). Rubber kreeg over het algemeen gunstige kritieken en werd vaak met 
Max Havelaar vergeleken in de zin dat beide werken de uitbuiting van de inheemse bevolking op een zo objectief mogelijke manier behandelden (Praamstra 2007: 92). Aan de andere kant, zoals Rudy Kousbroek dat vaststelt, was dit succes ook te danken aan het schandaal dat dit boek omgaf (Kousbroek 1992: 83). In zijn Oost-Indische Spiegel was Rob Nieuwenhuys van mening dat hoewel de schrijfster een zo realistisch mogelijk beeld van het Delische plantersleven probeerde te schetsen, het haar alleen in de details is gelukt. Haar Indische boeken zijn volgens hem eerder subjectieve beschrijvingen waarin Székely-Lulofs de unieke positie van de binnen- en buitenstaander op zichzelf heeft genomen, die van een 'participant observer' (Nieuwenhuys 1972: 351).

Ondanks het feit dat Madelon Székely-Lulofs één van de beroemdste schrijvers was in de jaren dertig in Nederland, was ze snel vergeten, vooral vanwege de negatieve kritieken van Menno ter Braak en Edgar du Perron (Praamstra 2006: 47). $\mathrm{Zij}$ hebben vooral de literaire kwaliteit van haar boeken betwijfeld en hebben haar succes toegeschreven aan de schandaligheid van haar thema's. Hoewel haar romans zich in Nederlands-Indië afspeelden, vertoonden ze de door Ter Braak zo gehate kenmerken van het 'huiskamerrealisme', waarmee de criticus haar werk in de categorie van de 'damesromans' heeft geplaatst (Praamstra 2006: 52). Annie Romein-Verschoor bekritiseerde de boeken van Székely-Lulofs vanuit een ander perspectief: volgens haar "voldeden [die] aan de markt-eis van het nieuwe thema" (Romein-Verschoor 1977: 163), wat volgens haar de oorzaak is van de Europese beroemdheid van de schrijfster, eerder dan de literaire kwaliteit van haar werken.

Koelie werd ook een succes - vooral de linkse pers reageerde positief - en werd in verschillende talen vertaald, maar kreeg verontwaardigde kritieken vooral in de Indische pers (Praamstra 2007: 99). Als vooraanstaande figuur in dit proces waarbij de Indische boeken van Székely-Lulofs afgewezen werden, moet de naam van de 'steunpilaar' van de extreemrechtse Vaderlandsche Club en hoofdredacteur van de Java-Bode H.C. Zentgraaff vermeld worden (Termorshuizen 2002: 113). Volgens hem kreeg het buitenland door deze werken een vals beeld van de Indische samenleving, waarin de inheemsen onderdrukt werden door de Nederlanders (Termorshuizen 2016: 134; Pusztai 2004: 270). De negatieve kritieken die Koelie kreeg, werden meestal gebaseerd op 'niet-literaire criteria': de roman werd vooral beschouwd als een politiek boek (Okker 2008: 122).

Als we kijken naar het typische "profiel" van een middlebrow-auteur (Van Boven 2009: 290-291), vinden we enkele overeenkomsten met de carrière en de Nederlandse receptie van Madelon Székely-Lulofs:

- haar romans hebben veel lezers gevonden in binnen- en buitenland;

- het gaat om een vrouwelijke auteur;

- haar roman Rubber werd verfilmd, wat ook het feit onderstreept dat het boek voor de massa bedoeld was;

- haar boeken toonden volgens de critici realistische kenmerken. 


\subsection{De Tsjechische en Poolse vertalingen}

Wat de aanwezigheid van vertaalde Nederlandse werken in deze periode betreft, lijken er duidelijke overeenkomsten te zijn tussen de tendensen in Hongarije, in Polen en in het voormalige Tsjechoslowakije. Ten eerste waren deze vertalingen in deze drie landen meestal gemaakt op basis van de Duitse vertalingen (Engelbrecht 2013: 165). Ten tweede werd de keuze van de uitgevers in deze drie landen bepaald door wat er in Duitsland verscheen (Engelbrecht 2013: 166). Deze verschijnselen zijn echter niet duidelijk aanwezig in het Hongaarse receptieproces van Madelon Székely-Lulofs: in de volgende hoofdstukken zullen we zien dat de Hongaarse vertalingen van haar werken niet altijd op de Duitse versie zijn gebaseerd. In haar geval is de invloed van de Duitse boekenmarkt op de Hongaarse ook minder bepalend: bij de beslissing van de Hongaarse uitgevers om haar werken uit te geven speelden haar persoonlijke contacten met de Hongaarse literaire kringen een grotere rol.

Wilken Engelbrecht vermeldt dat de Nederlandse literatuur in Tsjechische vertaling over het algemeen een "bescheiden plaats" heeft ingenomen (Engelbrecht 2016: 91), maar in zijn studie over de Nederlandse en Centraal-Europese receptie van Jo van Ammers-Küller voegt hij eraan toe dat schrijfsters van 'damesromans' wel relatief goed vertegenwoordigd waren binnen deze groep van vertalingen: naast Van Ammers-Küller verschenen er ook werken van Madelon Székely-Lulofs in het Tsjechisch (Engelbrecht 2013: 166). In Polen was Madelon Székely-Lulofs de enige Nederlandse auteur naast Herman Heijermans, Jo van Ammers-Küller en Herman de Man die in deze periode in vertaling uitkwam (Engelbrecht 2013: 173).

\section{Contact met Hongarije}

Zoals al eerder vermeld, dient Madelon Székely-Lulofs vanwege haar persoonlijke contact met Hongarije als een bijzonder voorbeeld van het receptieonderzoek. De schrijfster maakte kennis met de Hongaarse planter László Székely in Deli toen beiden voor het weekblad Sumatra werkten. Na de echtscheiding van haar eerste man, Hendrik Doffegnies, trouwden ze in Boedapest in september 1926 (Pusztai 2007: 14). Na een kort verblijf in Deli keerde het echtpaar naar Hongarije terug en leefden ze tussen 1930 en 1938 in Boedapest (Pusztai 2007: 16). In deze periode schreef Székely-Lulofs haar bekendste en succesvolste werken: Rubber (1931), Koelie (1932), De andere wereld (1934), De hongertocht (1936) en Het laatste bedrijf (1937). Al deze werken werden in het Hongaars vertaald, en drie daarvan werden ook in de toenmalige Hongaarse pers behandeld.

Székely-Lulofs en haar man hielden zich bezig met literair vertalen; ook tijdens hun achtjarig verblijf in Boedapest vertaalden ze veel. Door hun vertaalwerk werd 
het echtpaar het symbool van de literaire en culturele betrekkingen tussen Nederland en Hongarije in het interbellum (Sivirsky 1986: 34). Madelon Székely-Lulofs en haar man waren beiden van zeer groot belang voor de introductie in Nederland van vooraanstaande Hongaarse schrijvers, zoals Sándor Márai, Ferenc Körmendi, Jolán Földes, Zsolt Harsányi, Mihály Földi, Ferenc Molnár, Gábor Vaszary en anderen (Pusztai \& Termorshuizen 2007: 55). Omgekeerd werden door hun inspanningen boeken van onder meer Piet Bakker, Jan de Hartog en Karel Norel in Hongarije bekend (Pusztai \& Termorshuizen 2007: 55). Gábor Pusztai vermeldt verder dat het echtpaar ook met het Hongaarse literaire leven in contact is gekomen via Dezső Kosztolányi, schrijver, dichter en voorzitter van de PEN-club in Hongarije tussen 1930 en 1932 (Pusztai 2009: 23). Székely-Lulofs en Kosztolányi hebben elkaar leren kennen via Herman Robbers, uitgever van de schrijfster vanaf 1931 en bestuurslid van de Nederlandse PEN-club (Pusztai 2015: 94).

De persoonlijke contacten van de schrijfster met de Hongaarse literaire kringen hebben uiteraard in grote mate bijgedragen tot het feit dat haar werken überhaupt gerecipieerd werden in Hongarije. Zonder deze contacten zou de naam Madelon Lulofs bij Hongaarse critici waarschijnlijk niet eens bekend zijn geworden. Ondanks deze persoonlijke contacten bestonden er toch onjuistheden in verband met haar biografie, wat we hierna zullen zien.

\subsection{De Hongaarse vertalingen}

In het interbellum werden er vijf boeken van Madelon Székely-Lulofs in het Hongaars vertaald, waardoor zij na Herman Heijermans en Jo van Ammers-Küller in Hongarije een van de meest vertaalde Nederlandse auteurs werd. ${ }^{3}$ Koelie was het eerste boek dat in Hongaarse vertaling uitkwam, in 1934, met de titel Az öserdó rabjai [De gevangenen van het oerwoud]. Voor de vertaling was eerst Dezső Kosztolányi ingeschakeld, maar hij had de roman pas kunnen vertalen op basis van een Franse versie (Okker 2008: 125), die niet bestond. Uiteindelijk werd Koelie door schrijver en redacteur Andor Németh (1891-1953) uit het Duits vertaald. Németh was een belangrijke figuur van het Hongaarse literaire leven tussen de twee wereldoorlogen en vertaalde veel: uit het Frans, Engels en Duits (Pusztai 2015). ${ }^{4}$

Over de vertaler van De andere wereld (A másik világ, verscheen in 1937) en De hongertocht (Szumátrai járör [Patrouille op Sumatra], verscheen in hetzelfde jaar), László Pintér, is niet zo veel bekend. Zijn naam komen wij maar één keer tegen in de databank van de Hongaarse Nationale Bibliotheek: hij heeft de roman Daylight on Saturday (1943) van de Engelse schrijver John Boynton Priestley

${ }^{3}$ Van Herman Heijermans zijn er tien, van Jo van Ammers-Küller zijn er negen Hongaarse vertalingen bekend.

${ }^{4}$ Németh vertaalde onder andere werken van Victor Hugo, Honoré de Balzac, Reinhold Conrad Muschler, Octave Aubry, Sinclair Lewis, Émile Zola, Ernest Hemingway en Theodore Dreiser. 
vertaald in 1947 (Databank Hongaarse Nationale Bibliotheek). In de Hongaarse pers werd naar De hongertocht soms met de titel Szumátrai örjárat [Sumatraanse Patrouille] verwezen (Pusztai 2009: 19).

De Hongaarse vertaling van Rubber kwam voor de eerste keer in 1937 uit, en daarna werd die herdrukt in 1942. De vertaling werd gemaakt door György Kovács, die vooral Engelstalige literatuur vertaalde (Agatha Christie, Eric Knight, Sinclair Lewis). Aangezien de vertalers van De andere wereld, De hongertocht en Rubber niet uit het Nederlands vertaalden, kunnen we vaststellen dat deze romans ook uit een andere taal, uit het Duits of het Engels werden vertaald. Van de vijf in het Hongaars verschenen werken van Székely-Lulofs is Het laatste bedrijf hoogstwaarschijnlijk het enige dat direct uit het Nederlands werd vertaald. De vertaler was László Székely en het boek kwam uit in 1944 met de titel Utolsó kisérlet.

\subsection{Het Hongaarse literaire veld in de onderzochte periode - de literaire kritiek}

De houding van de contemporaine Hongaarse literaire kritiek vertoont enkele overeenkomsten met die van de Nederlandse. Zowel in Nederland als in Hongarije werden literaire werken die populair waren onder de lezers, door de critici als minder waardevol beschouwd (Deczki 2013: 82). In de Hongaarse letterkunde bestond een met de middlebrow-roman vergelijkbare categorie: de zgn. amusementsliteratuur die van hoge kwaliteit is. Het lezerspubliek van deze romans bestond uit de geletterde middenklasse, en de werken binnen deze categorie behandelden actuele thema's op een manier die vaak als oppervlakkig werd bezien (Deczki 2013: 82).

In de Hongaarse letterkunde stemt deze categorie romans niet per se overeen met die van de damesromans. Er waren namelijk mannelijke auteurs die als middlebrow-auteurs werden bestempeld en die dus ook door de kritiek werden afgewezen, bijvoorbeeld de internationaal bekende Ferenc Körmendi, van wie de werken onder andere ook in het Nederlands werden vertaald - door Madelon Székely-Lulofs (Gera 207). Een ander gezamenlijk punt in de Nederlandse en Hongaarse literaire kritiek van het interbellum is de "patriarchale literair-kritische traditie" (Pécsi 2009: 62) en de daarmee samenhangende negatieve aannames tegenover vrouwelijke auteurs (Pécsi 2009: 60).

\subsection{De tijdschriften}

Van de in totaal zeven boekbesprekingen die uit deze periode werden verzameld, zijn er drie in het literaire tijdschrift Literatura [Literatuur] verschenen. Dit politiek neutrale tijdschrift stelde zich de popularisatie van zowel de Hongaarse als 
van de buitenlandse literatuur ten doel (Bálint 2004: 29). Hoofdredacteur Géza Supka heeft verklaard dat de bedoeling van het tijdschrift was de belangstelling van het publiek op te wekken tot het lezen van literaire werken, vandaar dat de recensenten zelden een negatieve kritiek formuleerden met betrekking tot de literaire kwaliteit van een werk (Bálint 2004: 32).

De andere vier boekbesprekingen heb ik in vier verschillende tijdschriften en dagbladen gevonden: in de literaire tijdschriften Nyugat, Napkelet en Élet, en in het dagblad Pesti Napló. Nyugat [Het Westen] was het meest gezaghebbende literaire tijdschrift in de eerste helft van de $20^{\mathrm{e}}$ eeuw. Het tijdschrift proclameerde zijn programma al in zijn titel: Nyugat was voornamelijk gericht op het bekendmaken van de grote "Westerse" literaire werken. Nyugat kon zijn prestige vanaf 1908 meer dan drie decennia lang bewaren, vooral omdat het meestal politiek en economisch gezien autonoom kon blijven - dit laatste streven probeerde het tijdschrift te behouden door voor kwalitatieve literatuur te kiezen, vaak ten koste van de hoge oplagecijfers en winstgevendheid (Szolláth 2015: 168). In dit opzicht is Nyugat een uitstekend voorbeeld voor de dynamiek binnen het literaire veld in de algemene zin: de productie van de symbolische waarde staat heel vaak in tegenstelling met de productie van de economische of materiële waarde.

Een ander tijdschrift waarin een boekbespreking over Koelie te vinden is, is het literair-kritische tijdschrift Napkelet [Het Oosten]. Het tijdschrift werd in 1923 opgericht op initiatief van graaf Kunó Klebelsberg, Minister van Onderwijs in het toenmalige Hongarije. Zoals de titel van het tijdschrift ook zou kunnen suggereren, werd het opgericht als een soort tegenpool van Nyugat, in de zin dat Napkelet meer conservatief georiënteerd was en ernaar streefde de Hongaarse culturele 'superioriteit' in de regio te bewijzen door de Hongaarse intellectuele waarden te laten zien (Szolláth 2015: 170). Hoewel het tijdschrift dus een duidelijke politieke oriëntatie had, verschenen er meestal objectieve boekbesprekingen in, zonder politieke lading (Szolláth 2015: 170).

Het tijdschrift Élet [Leven] diende als een belangrijk platform vooral voor de Hongaarse katholieke schrijvers, maar het bood niet alleen de katholieke auteurs mogelijkheid tot publiceren aan, en naast boekbesprekingen werd er ook over de actualiteit geschreven. De bedoeling van de redacteurs van het in 1909 opgerichte tijdschrift was om een modern katholiek weekblad tot stand te brengen dat de rivaal van Nyugat zou kunnen worden (Szénási 2011: 48).

Pesti Napló [Pests Dagboek] was een politiek dagblad dat tussen 1852 en 1939 bestond. Het blad bracht tijdens zijn bijna 90-jarige bestaan verslag van Hongaarse en buitenlandse politieke, economische, wetenschappelijke en culturele gebeurtenissen. Na de Ausgleich in 1867 steunde Pesti Napló de regering, maar over het algemeen was het een onpartijdig dagblad waarin de belangrijkste vertegenwoordigers van het toenmalige Hongaarse literaire leven een plaats konden krijgen (Kosáry 1985: 59). 


\subsection{Madelon Székely-Lulofs in de Hongaarse pers: de artikelen}

In de Hongaarse pers van deze periode werden drie werken van de schrijfster behandeld: De andere wereld, Koelie en De hongertocht. Er werd geen boekbespreking over haar bekendste roman, Rubber, gepubliceerd, hoewel het in één van deze boekbesprekingen wel vermeld werd dat ze bekend is geworden om dit boek, dat in "alle Europese talen" vertaald werd (Bodó 1937: 36).

$\mathrm{Al}$ de boekbesprekingen werden vlak na het verschijnen van de respectievelijke Hongaarse vertalingen gepubliceerd, ze zijn dus in elk geval gebaseerd op de Hongaarse vertalingen. Over De andere wereld werd in twee artikelen geschreven: in Élet op 23 augustus 1936 (Erdősi 1936: 23), en in Literatura op 1 september 1936 (Anoniem 1936: 253). Erdősi verwijst naar Székely-Lulofs als iemand die "het leven op Sumatra heel goed kent" en in deze wereld "behalve de eeuwige zonneschijn meestal de diepte van de schaduwen ziet" (Erdősi 1936: 23). Ze beschrijft dus een verdrietige wereld in haar werk; een wereld waarin de "levenslust van de onderdrukten toch tot uitbarsting komt" (Erdősi 1936: 23). De enige mogelijkheid voor de hoofdpersoon, de blanke planter, aan deze wereld te ontsnappen is de hoop op "de echte andere wereld: die van na de dood" (Erdősi 1936: 23). Volgens Erdősi beschrijft Székely-Lulofs de relatie tussen de hoofdpersoon en zijn concubine "op een onrealistische een misleidende manier; het is namelijk algemeen bekend dat de inheemse altijd een bediende blijft tegenover de blanke en dus niet in staat is om hem lief te hebben" (Erdősi 1936: 23). De anonieme recensent van Literatura schrijft minder nauwkeurig over De andere wereld: "in deze roman zien we het geestdodende, eentonige plantersleven" met Pieter in de voorgrond, die werkt "als een trekdier om eindelijk een rijke heer te kunnen worden" (Anoniem 1936: 253). Hij moet zich echter realiseren dat dit leven hem geen echte vreugde brengt: hij voelt zich zo vreemd in deze wereld dat hij kiest ervoor zijn leven weg te gooien (Anoniem 1936: 253).

Ook de titel Koelie komen we twee keer tegen: in Literatura op 1 november 1934 (Anoniem 1934: 334), en in Napkelet op 1 februari 1935 (Esty 1935: 131132). De recensent van Literatur beschrijft Székely-Lulofs als "een talentvolle schrijfster die de Javaanse ziel perfect kent" omdat zij haar kindertijd op het eiland doorbracht. Koelie werd in deze boekbespreking zelfs met De hut van oom Tom van Harriet Beecher Stowe vergeleken in het opzicht dat het boek van de Amerikaanse schrijfster "de beweging [startte] die tot de afschaffing van de Amerikaanse slavernij leidde" (Anoniem 1934: 334). Székely-Lulofs laat in deze roman de uitbuiting van de Javaanse koelies zien, en "naast [deze]sociologische waarheden kunnen de lezers ook de charme van dit exotische landschap leren kennen" (Anoniem 1934: 334). In de andere recensie over Koelie schrijft Esty het volgende: "door de beschrijving van het onmenselijke lijden van de koelies wordt de schrijfster woordvoerder en tegelijkertijd veroordelaar van haar Nederlandse broers en van hun mishandelingen die misschien niet altijd opzettelijk zijn" (Esty 1935: 131). De roman is volgens 
de recensent een "waardevolle psychografie" die alleen tot stand kon komen omdat Székely-Lulofs deze gebeurtenissen daadwerkelijk beleefde (Esty 1935: 132).

Er kwamen drie artikelen over De hongertocht uit: in het dagblad Pesti Napló op 5 december 1937 (Bodó 1937:36), in Literatura op 1 januari 1937 (Anoniem 1937: 441) en in Nyugat, in het eerste nummer van 1938 (Nagypál 1938: 87). Deze boekbesprekingen werden in de bijdrage van Gábor Pusztai nauwkeurig besproken (Pusztai 2009: 19-21). In deze recensies over De hongertocht komt de nadruk op de sociale gevoeligheid van de schrijfster voor die parallel gaat met het psychologische aspect van haar romans: omdat zij in Nederlands-Indië is opgegroeid, is zij in staat niet alleen het exotische landschap, maar ook "de ziel van de Javanen" (Nagypál 1938: 87) op een zo authentiek mogelijke manier te beschrijven. Het realistische karakter van haar romans komt duidelijk positief voor in deze boekbesprekingen, het draagt namelijk bij tot het ontkrachten van de mythe die deze wereld meestal omringt (Nagypál 1938: 87). Met andere woorden, door haar boeken leert de Hongaarse lezer ook de sombere, verdrietige, "geestdodende" (Nagypál 1938: 87) kant van het leven op Sumatra kennen. Volgens Nagypál zijn de boeken van Székely-Lulofs "sensationeel interessant" en "desondanks van hoge literaire kwaliteit" (Anoniem 1937: 441) - opvallend hier is de verwachting dat een "interessant" literair werk niet van hoge kwaliteit kan zijn.

Op basis van de zeven boekbesprekingen waaruit mijn corpus bestaat, kan over de Hongaarse receptie van Székely-Lulofs vastgesteld worden dat er een positief beeld is ontstaan over deze drie romans onder de Hongaarse recensenten en dat de algemene negatieve houding van de Hongaarse literaire kritiek tegenover middlebrowromans en vrouwelijke auteurs in deze artikelen niet verschijnt. Er bestaan echter onzekerheden i.v.m. haar leven; één van de critici vermeldt bijvoorbeeld dat zij "ergens in Nederlands-Indië" werd geboren (Esty 1935: 131). Het gebrek aan kennis over Madelon Székely-Lulofs en over de Nederlandse literatuur over het algemeen werd ook heel duidelijk geïllustreerd in een interview met Jo van Ammers-Küller uit 1942 in het Hongaarse dagblad Esti Magyarország. In dit interview kwam onder andere de (on)bekendheid van de Nederlandse literatuur in Hongarije ter sprake: de journalist informeert ons dat "het echtpaar Lulofs" tot de verspreiding van literaire werken tussen Nederland en Hongarije bijdraagt met hun vertaalwerk en dat de schrijfster, die "Mária Székely" heet, "van Hongaarse afkomst" is (Pusztai 2009: 24).

\section{Slot - de verschillen tussen het Nederlandse en het Hongaarse literaire veld}

De Nederlandse literatuur was tussen de twee wereldoorlogen in Hongarije nauwelijks bekend; de receptie van Madelon Székely-Lulofs vormde hierop geen uitzondering. De analyse van de Hongaarse receptie van de schrijfster laat de uiteenlopende structuur van de literaire velden van de twee landen zien. 
De twee belangrijkste factoren die de aandacht van de Hongaarse critici op het werk van Székely-Lulofs hebben getrokken, waren aan de ene kant haar internationale bekendheid, en aan de andere kant haar persoonlijke contact met Hongarije door haar man László Székely en uiteraard het feit dat het echtpaar in de jaren dertig in Boedapest woonde. Toch bleef Madelon Székely-Lulofs in het Hongaarse literaire leven een "randfiguur" (Pusztai 2009: 11), wat vooral te wijten is aan de marginale positie van de Nederlandse literatuur in Hongarije in het algemeen en aan de thematiek van haar werken, die het Hongaarse lezerspubliek onbekend voorkwam. Maar zodra haar werken gerecipieerd werden door de Hongaarse boekenmarkt en vervolgens door de Hongaarse pers, bleek dit laatste kenmerk een verdienste te zijn, waardoor de schrijfster een soort reisgids werd, die de Hongaarse lezers in deze exotische wereld inwijdde. De afstand tussen de twee literaire velden resulteerde op deze manier in een positieve beoordeling van de schrijfster.

Wat in de Nederlandse boekbesprekingen als tekortkoming verscheen, met name het feit dat het hier om een vrouwelijke auteur gaat en de tegenstelling tussen economisch succes en literaire kwaliteit, werd in de Hongaarse receptie buiten beschouwing gelaten- ondanks de algemene afkeer van de Hongaarse critici jegens populaire literaire werken. Ter Braak sprak nog over het gebrek aan psychologisch inzicht bij Székely-Lulofs, terwijl in Hongarije de schrijfster juist als de kenner van de Javaanse ziel verscheen.

Een factor die bepalend bleek voor haar Nederlands-Indische receptie was het politieke aspect van haar werken, waardoor ze afgewezen werd door de Indische pers. In de door mij gevonden artikelen is dit aspect in de achtergrond geraakt - of tenminste werd de schrijfster niet bekritiseerd om dit aspect omdat de politieke situatie in Indië waarschijnlijk niet bekend was in Hongarije - en de romans van Székely-Lulofs werden eerder als avonturenboeken beschouwd. In dit geval had het Hongaarse politieke veld geen invloed op het literaire, in tegenstelling tot in de Nederlands-Indische situatie.

\section{Bibliografie}

Anoniem (1934): “Az öserdő rabjai.” Literatura 9, 21: 334.

Anoniem (1936): “A másik világ”. In: Literatura 11, 17: 253.

Anoniem (1937): "Szumátrai járőr". In: Literatura 12, 1: 441.

Bálint, Gábor (2004): “Supka Géza folyóirata, a Literatura (1926-1938)”. In: Magyar Könyvszemle 120, 1: 29-51.

Béládi, Miklós \& Rónay, László (1990): A magyar irodalom története 1945-1975. Boedapest: Akadémiai Kiadó.

Bodó, Béla (1937): “Szumátrai járőr". In: Pesti Napló 88, 277: 36.

Bork, G.J. van e.a. (2012-2016): Algemeen letterkundig lexicon. Digitale Bibliotheek voor de Nederlandse Letteren, laatst geraadpleegd op 15.01.2017 (http://www.dbnl.org/tekst/dela012alge01_01/colofon.phpGeraadpleegd). 
Bork, G.J. van \& Laan, Nico (2010): Van Romantiek tot Postmodernisme. Opvattingen over Nederlandse literatuur. Bussum: Uitgeverij Coutinho.

Bourdieu, Pierre (1993): The Field of Cultural Production. Essays on Art and Literature. New York: Columbia University Press.

Boven, Erica van (2009): "De middlebrow-roman schrijft terug. Visies op elite en 'hoge literatuur' in enkele publieksromans rond 1930". In: Tijdschrift voor Nederlandse Taal- en Letterkunde 125, 3: 285-305.

Csepregi, Klára (2008): Holland (flamand, fríz, németalföldi, afrikaans) - magyar bibliográfia. Hollandián kivül és Magyarországon megjelent írások. Boedapest: Országos Széchényi Könyvtár.

Deczki, Sarolta (2013): "Vészterhes emberöltők: Körmendi Ferenc három regénye". In: Schein, Gábor \& Szücs, Teri (ed.): "Zsidó” identitásképek a huszadik századi magyar irodalomban. Boedapest: ELTE, 81-90.

Engelbrecht, Wilken (2013): “Een boegbeeld van de morele sanering - Jo van Ammers-Küller”. In: Van Heuckelom, Kris e.a.: Van Eeden tot heden. Literaire dwarsverbanden tussen MiddenEuropa en de Lage Landen. Gent: Academia Press, 155-185.

Engelbrecht, Wilken (2016): "Het ontstaan van de idee 'Nederlandstalige literatuur' in Tsjechië". In: Werkwinkel: Tijdschrift voor Nederlandse en Zuid-Afrikaanse Studies 11, 1: 73-94.

Erdősi, Károly. (1936): “Lulofs Madelon: A másik világ”. In: Élet 27, 34: 23.

Esty, Pál (1935): “Az őserdő rabjai”. In: Napkelet 13, 2: 131-132.

Gera, Judit (2013): "De Hongaarse, Nederlandse en Vlaamse receptie van De straat vande vissende kat van de Hongaarse schrijfster Jolán Földes". In: Van Heuckelom, Kris e.a.: Van Eeden tot heden. Literaire dwarsverbanden tussen Midden-Europa en de Lage Landen. Gent: Academia Press, 199-218.

Kosáry, Domokos \& Németh, Béla G. (1985): A magyar sajtó története 1867-1892. Boedapest: Akadémiai Kiadó.

Kousbroek, Rudy (1992): Het Oostindisch kampsyndroom. Amsterdam: Meulenhoff.

Nagypál, István (1938): "Szumátrai örjárat. Madelon Lulofs regénye". In: Nyugat 31, 1: 87-89.

Nieuwenhuys, Rob (1972): Oost-Indische spiegel. Wat Nederlandse schrijvers en dichters over Indonesië hebben geschreven vanaf de eerste jaren der Compagnie tot op heden. Amsterdam: B.M. Querido's Uitgeverij.

Okker, Frank (2008): Tumult. Het levensverhaal van Madelon Székely-Lulofs. Amsterdam/Antwerpen: Atlas.

Pécsi, Emöke (2009): A másság (de)konstrukciója Carry van Bruggen korai prózájában. Boedapest: ELTE.

Praamstra, Olf (2006): "Begraven en weer opgestaan, de literaire waardering van Madelon SzékelyLulofs". In: Praagse perspectieven 4: 47-59.

Praamstra, Olf (2007): "Ontworteld. Waarom Madelon Székely-Lulofs verder zag dan haar tijdgenoten (en ervan schrok)". In: Acta Neerlandica 5: 89-109.

Pusztai, Gábor (2004): "Rágalomhadjárat vagy kordokumentum? Székely László Őserdőktől az ültetvényekig címủ mủvének fordításai és hollandiai recepciója”. In: Könyv és Könyvtár 26: 267-281.

Pusztai, Gábor (2007): “Inleiding”. In: Acta Neerlandica 5: 9-23.

Pusztai, Gábor (2009): "De 'schrijfster van de Javaanse slaven”". In: Acta Neerlandica 7: 9-25.

Pusztai, Gábor (2015): “A magyar irodalom hollandiai nagykövetei. Madelon Lulofs és Székely László műfordítói tevékenységéről”. In: Alföld 66, 2: 93-101.

Pusztai, Gábor \& Termorshuizen, Gerard (2007): "De tweede man. Het huwelijk van Madelon Lulofs en László Székely”. In: Acta Neerlandica 5: 49-62.

Rees, C.J. van \& Dorleijn, G.J. (1993): De impact van literatuuropvattingen in het literaire veld. Aandachtsgebied literaire opvattingen van de Stichting Literatuurwetenschap. Den Haag: Stichting Literatuurwetenschap. 
Romein-Verschoor, Annie (1977): Vrouwenspiegel. Een literair-sociologische studie over de Nederlandse romanschrijfster na 1880. Nijmegen: SUN.

Sanders, Matthijs (2008): "De criticus als bemiddelaar. Middlebrow en de Nederlandse literaire kritiek in het interbellum". In: Tijdschrift voor Nederlandse Taal- en Letterkunde. 124, 4: 312-333.

Sivirsky, Antal (1986): A holland-magyar kulturális kapcsolatok öt évszázada. Budapest: Terra.

Szénási, Zoltán (2011): “A modernség kalandja. A katolikus irodalom modernizációs kísérlete - az Élet 1909-1914”. In: Finta, Gábor e.a. (ed.): A Nyugat párbeszédei. A magyar irodalmi modernizáció kérdései. Budapest: Argumentum, 47-55.

Szolláth, Dávid (2015): “Magyar irodalmi mező az 1920-as években”. In: Literatura 41, 2: 161-184.

Termorshuizen, Gerard (2002): "Indië is ook in het litterarische eene melkkoe". In: D'haen, Theo (ed.): Europa buitengaats. Koloniale en postkoloniale literaturen in Europese talen. Deel 1. Amsterdam: Uitgeverij Bert Bakker, 98-132.

Termorshuizen, Gerard (2016): "H.C. Zentgraaff contra het echtpaar Székely-Lulofs". In: Acta Neerlandica 12: 133-143.

\section{Website}

Databank van de Hongaarse Nationale Bibliotheek, http://nektar.oszk.hu (laatst geraadpleegd op 15.01.2017).

Zsuzsa Tóth $(* 1986)$ studeerde Nederlands en Engels aan de Universiteit Debrecen. Zij is momenteel PhD-studente en assistente van Vakgroep Nederlands aan de Universiteit Debrecen. Zij doet onder leiding van dr. Gábor Pusztai onderzoek naar de $20^{\mathrm{e}}$-eeuwse receptie van de Nederlandse literatuur in Hongarije.

e-mail: bubosbanka86@yahoo.com 